\title{
Expression of Estrogen and Progesterone Receptors in the Bovine Ovary During Estrous Cycle and Pregnancy
}

\author{
Bajram Berisha, Michael W. Pfaffl, and Dieter Schams \\ Institute of Physiology, Technical University Munich-Weihenstephan, D-85350 Freising, Germany
}

The objective of the study was to demonstrate the mRNA expression of estrogen receptor $\alpha(E R \alpha), E R \beta$, and progesterone receptor (PR) by block reverse transcription-polymerase chain reaction(RT-PCR) and real-time RT-PCR (LightCycler) in bovine ovarian follicles and in corpus luteum during the estrous cycle and pregnancy. The mRNA expression of ER $\alpha$ and ER $\beta$ mRNA in theca interna tissue (TI) (lower pg/ug RNA) increased continuously and significantly during final growth of follicles, with much higher levels for ER $\alpha$. The mRNA expression of $E R \alpha$ and $E R \beta$ in granulosa cells (GC) (fg/ $\mu \mathrm{g}$ RNA) increased continuously during follicle growth but without any significant change. The expression of mRNA for PR in follicles (lower fg/ $\mu g$ RNA) increased continuously to maximum level in preovulatory follicles with a significant change only in TI. The highest mRNA expression for $E R \alpha$ ( $f g / \mu g$ RNA) was detected in corpus luteum (CL) during the early luteal phase, following by a significant decrease of expression during the mid, late, and regression phases. In contrast, ER $\beta$ mRNA expression is relatively high during the early stage, decreased during the late early and mid luteal phase, and increased significantly again during the late luteal phase and after CL regression. During pregnancy ( $>3$ mo), low levels of $E R \alpha$ and $E R \beta$ mRNA expression $(<25 \mathrm{fg} / \mu \mathrm{g}$ RNA) with no significant changes were measured. No significant change in PR mRNA expression (levels $<13 \mathrm{fg} / \mu \mathrm{g}$ RNA) during the estrous cycle and pregnancy in bovine $\mathrm{CL}$ were found. The results suggest an autocrine/paracrine role of steroid receptors in the regulation of final follicle growth and corpus luteum formation and function.

Key Words: Bovine ovary; steroid; receptor; expression.

\section{Introduction}

The ovarian steroid hormones estrogen (E) and progesterone (P) fulfill a number of important functions related to reproduction by endocrine mechanisms of action. In addi-

Received February 6, 2002; Revised March 26, 2002; Accepted March 26, 2002.

Author to whom all correspondence and reprint requests should be addressed: Dr. Dieter Schams, Institute of Physiology, Technical University MunichWeihenstephan, D-85350 Freising, Germany. E-mail: physio@wzw.tum.de tion to acting as hormones on structures remote from the ovary, the steroids produced by follicle or corpus luteum cells also act locally within the follicles or corpora lutea as paracrine/autocrine agents, acting on or within the cells in which they are produced (1).

The genomic effects of $E$ and $P$ are mediated through interaction with specific intracellular receptors that are members of the nuclear receptor family. Binding of the steroids to their receptors induces structural and functional changes in receptor structure that culminate in an association of ligandreceptor complexes with specific target genes to regulate their transcription (1). Cloning and sequencing of estrogen receptor $\beta$ (ER $\beta$ ) in humans (2), rat (3), and mouse (4) has provided the first example of an ER existing in two isoforms, each of which is encoded by a separate gene. The ER $\beta$ protein is smaller than the previously identified ER $\alpha(5,6)$, but it possesses the modular structure of distinct functional domains (A-F) characteristic for members of the nuclear receptors. The DNA-binding domain of ER $\alpha$ and ER $\beta$ is highly conserved over several species ( $>95 \%$ homology in Homo sapiens, Rattus norwegicus, Mus musculus, Bos taurus) and the ligand-binding domains show approx $60 \%$ conserved residues (7-9). To act on specific cell types in the ovary, ovarian estrogen receptors must be present to induce gene activation (genomic actions). Some studies also indicate that estrogen receptors reside on the plasma membrane and modulate cellular activity without directly associating with DNA (nongenomic actions). ER $\alpha$ and ER $\beta$ tissue distributions and relative levels of expression are quite different because various tissue express either one or both receptors (10). Most tissue of reproductive organs in rat express both $\operatorname{ER} \alpha$ and $\operatorname{ER} \beta(11,12)$ and the relative expression levels of these receptors may play a major role in mediating $\mathrm{E}$ actions in a particular tissue.

In contrast to $\mathrm{E}$, receptors for $\mathrm{P}$ are expressed as two protein isoforms, PR-A and PR-B, that arise from a single gene (13). Both isoforms of PR are expressed in a number of vertebrate species, including rodents (14) and humans (15), and the ratios of the individual isoforms vary in reproductive tissue as a consequence of developmental (14) and hormonal status (16). Although the physiological significance of these variations is unknown, the conservation of these two receptor isoforms and the elaborate genomic mechanisms for their generation suggest that their differential 
expression may be crucial for the appropriate cellular responses to P (17). Corresponding PR isoforms are not yet demonstrated in large domestic animals.

In the ovary of domestic animals, ER $\alpha$ and ER $\beta$ expression were demonstrated in bovine, sheep, and pig follicles ( 9 , 18-20) and corpora lutea (20-22). The expression of PR was proved in humans $(23,24)$, mouse (25) and rat (26), as well as in bovine and sheep follicular and luteal tissue (27-30).

However, limited information exists about quantification and temporal changes of ER $\alpha, E R \beta$ and PR mRNA expression during final follicle growth, corpus luteum (CL) development, and function during the estrous cycle and pregnancy in the bovine ovary. The aim of the present study was to evaluate the expression pattern of mRNA for ER $\alpha, E R \beta$, and PR by sensitive, quantitative and reliable real-time reverse transcription-polymerase chain reaction (RT-PCR) $(31,32)$ in bovine antral follicles during final growth to the preovulatory stage and in luteal tissue by collection of CL from different stages during the estrous cycle and pregnancy.

\section{Results}

\section{Confirmation of Primer \\ Specificity and Sequence Analysis}

For exact length verification, RT-PCR products were separated on 2\% high-resolution agarose gel electrophoresis. Amplified gradient MasterCycler and LightCycler PCR products (Fig. 1) showed a single band and the expected length of $234 \mathrm{bp}$ for ER $\alpha, 262 \mathrm{bp}$ for ER $\beta, 227 \mathrm{bp}$ for PR, and $197 \mathrm{bp}$ for glyceraldehyde-3-phosphate dehydrogenase (GAPDH). Specificity of the desired products was additionally documented with the melting curve analysis of Light Cycler Software 3.39 (Roche Diagnostics, Mannheim, Germany). The melting temperature of the high specific products are species- and receptor-subtype-dependent between $83.0^{\circ} \mathrm{C}$ and $83.3^{\circ} \mathrm{C}$ for PR, $85.0^{\circ} \mathrm{C}$ and $86.0^{\circ} \mathrm{C}$ for $\mathrm{ER} \alpha, 88.8^{\circ} \mathrm{C}$ and $89.3^{\circ} \mathrm{C}$ for $\mathrm{ER} \beta$, and $87.9^{\circ} \mathrm{C}$ and $88.8^{\circ} \mathrm{C}$ for GAPDH. Sequence analysis (MWG Biotech, Ebersberg, Germany) of cloned steroid receptor RT-PCR products from Bos taurus showed $100 \%$ homology to the published sequences (32).

\section{Real-Time RT-PCR Assay Validation in Ovarian Tissues}

All performed real-time assays were product-specific, and effective PCR amplification kinetic was shown by high PCR efficiency (Table 1). Assay sensitivities were confirmed by detection limits down to 30 attogram (ag) (less than 14 single-stranded DNA [ssDNA] steroid receptor molecules) and linear quantification ranges over seven orders of magnitude from ag to nanogram concentrations $\left(10^{2}-10^{9}\right.$ molecules per capillary). Intra-assay and interassay variation of $<19 \%$ and $<30 \%$, respectively, were determined over the entire quantification range (31). The advantage of a hightemperature fluorescence acquisition in the fourth segment during the amplification program results in reliable and

\section{A $\mathrm{ER} \alpha$}

$234 \mathrm{bp}$

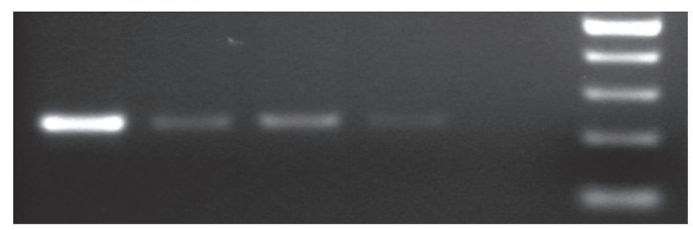

B ERB

262 bp
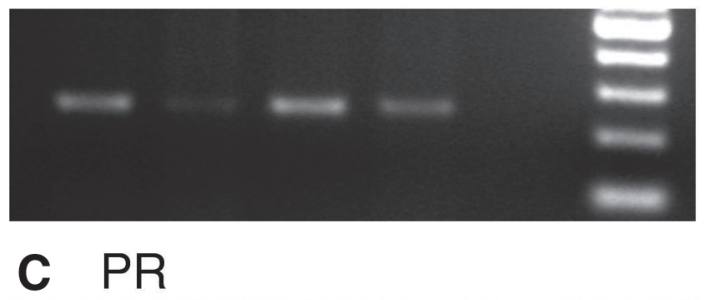

227 bp

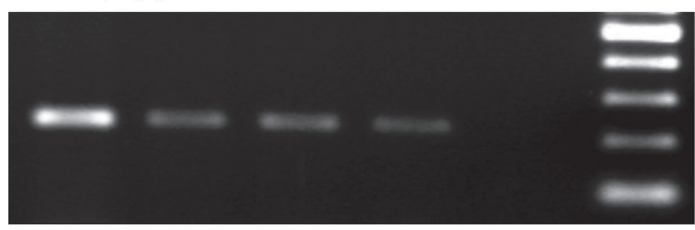

\section{GAPDH}

$197 \mathrm{bp}$

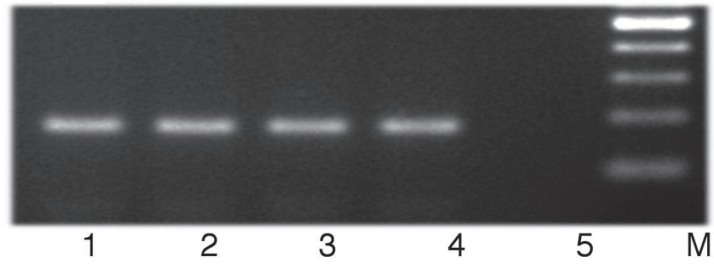

Fig. 1. Representative sample of specific RT-PCR products for (A) ER $\alpha$ (234 bp), (B) ER $\beta$ (262 bp), (C) PR (227 bp), and (D) GAPDH (197 bp) from (1) bovine endometrium, (2) corpus luteum, (3) theca interna, (4) granulosa cells, (5) no template control, and (M) DNA mass ladder (100-500 bp), separated by agarose gel electrophoresis.

sensitive ER-subtype-specific quantification with high linearity (Pearson correlation coefficient; $r>0.995$ ) over a wide range. High- temperature fluorescence acquisition melts the unspecific PCR products at $81^{\circ} \mathrm{C}, 82^{\circ} \mathrm{C}, 85^{\circ} \mathrm{C}$, and $87^{\circ} \mathrm{C}$, respectively, eliminates the nonspecific fluorescence signal derived from primer dimers and ensures an accurate quantification of the desired products.

\section{Tissue-Specific mRNA Expression}

Bovine $\mathrm{ER} \alpha, \mathrm{ER} \beta, \mathrm{PR}$, and GAPDH mRNAs were amplified by conventional RT-PCR, then cloned and sequenced $(31,32)$. A representative example for the PCR products of all factors in endometrium, corpora lutea, theca interna tissue, and granulose cells are shown in Fig. 1. To quantify ER $\alpha$, ER $\beta$, and PR transcripts also in low-abundant tissue, sensitive and reliable real-time RT-PCR quantification methods were developed and validated on the LightCycler. The mRNA expression results indicate the existence of GAPDH, ER $\alpha$, $\mathrm{ER} \beta$, and PR in all investigated tissue in the bovine ovary. In general, the mRNA expression data obtained by block 
Table 1

Characteristics and Validation Parameters of Real-Time RT-PCR Assays ${ }^{a}$

\begin{tabular}{lccc}
\hline & $\mathrm{ER} \alpha$ & $\mathrm{ER} \beta$ & $\mathrm{PR}$ \\
\hline Produce Length & $234 \mathrm{bp}$ & $262 \mathrm{bp}$ & $227 \mathrm{bp}$ \\
Detection limit & $5 \mathrm{ag}$ & $7 \mathrm{ag}$ & $30 \mathrm{ag}$ \\
Quantification limit & $404 \mathrm{ag}$ & $24 \mathrm{ag}$ & $1.7 \mathrm{fg}$ \\
Quantification range & $404 \mathrm{ag}-4.4 \mathrm{ng}$ & $24 \mathrm{ag}-24.4 \mathrm{ng}$ & $1.7 \mathrm{fg}-17 \mathrm{ng}$ \\
$\quad$ (test linearity) & $(r=0.995)$ & $(r=0.996)$ & $(r=0.998)$ \\
PCR efficiency & 1.81 & 1.82 & 1.94 \\
Intraassay variation & $18.7 \%(n=4)$ & $17.6 \%(n=4)$ & $5.7 \%(n=4)$ \\
Interassay variation & $28.6 \%(n=4)$ & $29.7 \%(n=4)$ & $25.7 \%(n=4)$ \\
\hline
\end{tabular}

${ }^{a}$ Intraassay and interassay variation of real-time RT-PCR assays were determined over the complete quantification range. Detection limit, quantification limit, and variations were based on concentrations per capillary.

RT-PCR were confirmed by quantitative real-time RT-PCR (LightCycler).

The mRNA expression of the housekeeping gene (GAPDH) resulted in constant expression levels in all investigated ovarian tissues. No significant differences could be determined between groups.

The mRNA expression of both ER subtypes in follicle increased continuously and correlates to follicle size and estradiol-17 $\beta\left(\mathrm{E}_{2}\right)$ concentrations. In theca interna tissue, ER $\alpha$ and ER $\beta$ mRNA expression increased continuously and significantly during final growth of follicle, with a higher level for ER $\alpha$ (Fig. 2A). The mRNA expression of both ER subtypes in granulosa cells (GC) tended to increase continuously during follicle growth but without any significant change (Fig. 2B). The absolute expression level was much lower as compared with theca interna tissue. The expression of mRNA for PR in follicle increased continuously to a maximum level in preovulatory follicle with significant change only in TI (Fig. 2C). Absolute concentrations (lower $\mathrm{fg} / \mu \mathrm{g}$ RNA level) were much lower in comparison to ER.

Estrogen receptors were differently expressed in bovine CL (Fig. 3A,B). The highest mRNA expression for ER $\alpha$ in corpus luteum (Fig. 3A) was detected during the early luteal phase, followed by a significant decrease of expression during the mid (d 8-12), late (d 13-16), and regression phase. In contrast, ER $\beta$ mRNA expression (Fig. 3B) was relatively high during the early luteal phase, decreased during the mid luteal phase (d 5-12), and increased significantly again during the late luteal phase (d 13-16) and after CL regression. During pregnancy low levels of ER $\alpha$ and ER $\beta$ mRNA expression $(<25 \mathrm{fg} / \mu \mathrm{g}$ RNA) with no significant changes were always present. No significant change in PR mRNA expression ( $<13 \mathrm{fg} / \mu \mathrm{g}$ RNA) was found during the estrous cycle and during pregnancy in bovine CL (Fig. 3C).

\section{Discussion}

In follicles, our results demonstrate a relative high mRNA expression of $E R \alpha$ and $E R \beta$ in theca interna tissue $(\mathrm{pg} / \mu \mathrm{g}$
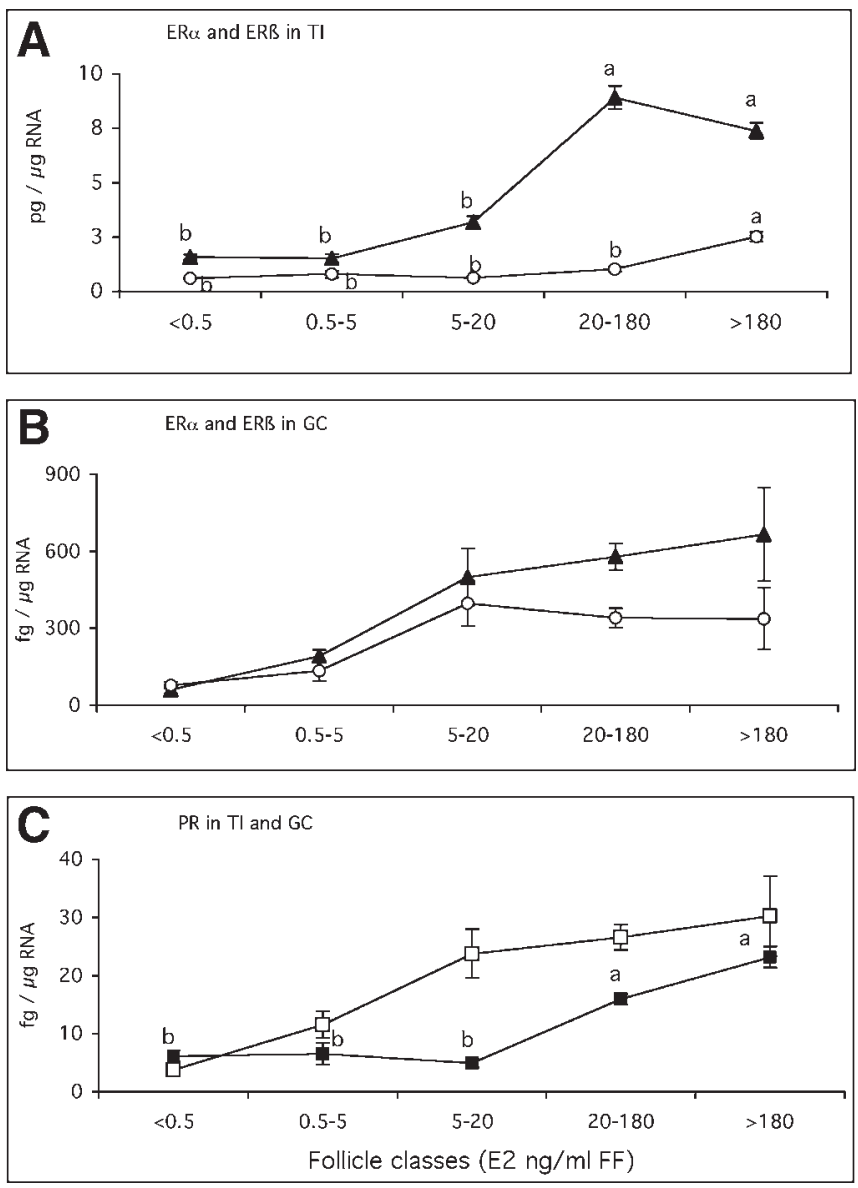

Fig. 2. Tissue-specific ER $\alpha, E R \beta$, and PR mRNA expression (LightCycler real-time RT-PCR) in different bovine follicle classes: (A) ER $\alpha$ in TI (A) and $\mathrm{ER} \beta$ in TI (O); (B) ER $\alpha$ in GC $(\boldsymbol{\Delta})$ and $\mathrm{ER} \beta$ in GC (O); (C) PR in TI (ם) and PR in GC ( $\square$ ). Results (concentration of mRNA/ $\mu$ g total RNA) represent means \pm SEM from 4-5 follicles/class. Different superscript letters indicate significant differences between groups $(p<0.05)$.

RNA) in comparison with granulosa cells (fg/ $\mu \mathrm{g}$ RNA). Furthermore, ER $\alpha$ is the dominating receptor in TI in contrast to GC, where the levels of ER $\alpha$ and ER $\beta$ are similar.

It is known from literature that both estadiol-17 $\beta\left(\mathrm{E}_{2}\right)$ and catecholestrogens can regulate the production of androgen and $\mathrm{P}$ within bovine and pig ovaries (33-36). The theca cells produce androgens, which are then, in general, taken up by granulosa cells and converted by $\mathrm{P} 450$-aromatase to estrogens. The data provide evidence that a local feedback loop may exist in ovarian follicles, where androgens produced by theca cells are used as a substrate for granulosa cell aromatization into E, which, in turn, may provide feedback to stimulate theca cell production of androgens (3338). For the full function of this feedback loop, the upregulation of $E R \alpha$ may play an important role. As shown for sheep myometrium and endometrium, ER is upregulated by $E_{2}$ (39). The upregulation of ER $\alpha$ and $E R \beta$ mRNA in 

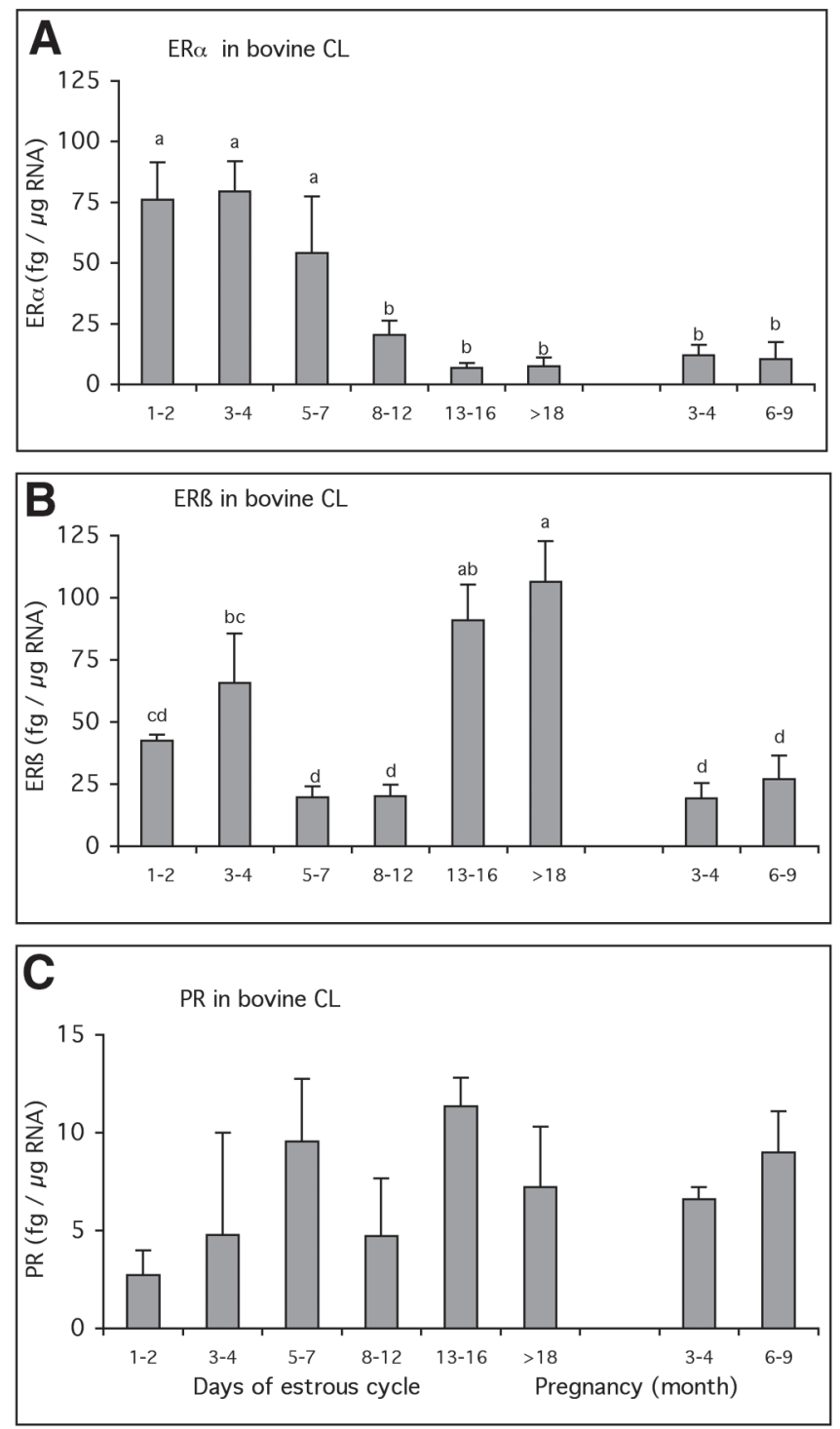

Fig. 3. Steroid receptor mRNA expression (LightCycler real-time RT-PCR) in bovine CL during the estrous cycle and pregnancy: (A) ER $\alpha$, (B) ER $\beta$, and (C) PR. Results (concentration of mRNA/ $\mu \mathrm{g}$ total RNA) represent means \pm SEM from 4-6 CLs/stage. Different superscript letters indicate significant differences between groups $(p<0.05)$.

our follicles correlates quite well with increasing levels of $\mathrm{E}$ in follicular fluid (FF). The expression levels for PR increased in parallel to ERs in follicles. Progesterone in sheep uterus antagonizes the effect of E to increase ER gene expression and active ER synthesis in nonpregnant sheep uterus (39). Our results suggest that progesterone and PR may control the stimulating effect of $E$ on the expression of ER receptors. $E_{2}$ has a direct transcriptional effect on vascular endothelial growth factor (VEGF) gene expression (40). VEGF is known to mediate angiogenic activity in variety of $\mathrm{E}$ target tissues. VEGF mRNA expression increased in parallel with E levels in bovine FF in GC and TI (41). Part of the ER action could be the upregulation of LH receptor (LHR) and follicle-stimulating hormone (FSH) receptor (FSHR) as shown for rat granulosa cells (42). An increase of LHR mRNA in TI and FSHR, and LHR in GC were demonstrated in the same tissue samples (41). Both ER $\alpha$ and ER $\beta$ activate transcription. They can work in opposite directions and activate protein- 1 response elements. In general, $E R \alpha$ is an activator and ER $\beta$ is an inhibitor or without effects on activating protein- 1 sites (43). The parallel increase of ER $\beta$ in TI at a lower level in comparison to ER $\alpha$ is in accordance with this hypothesis. The expression of ER $\alpha$ may be controlled by ER $\beta$. In GC, the mRNA expression for $\mathrm{ER} \alpha$ and $\mathrm{ER} \beta$ (Fig. 2B) is similar and generally on a much lower level. ER $\alpha$ is no longer the dominating ER. Both ER receptors show a tendency of upregulation parallel to increasing $E_{2}$ levels in FF. This upregulation correlates with an upregulation of LHR and FSHR (41).

Our results for $E R \alpha$ and $E R \beta$ mRNA expression in general agree with observations in ewe and pig $(18,20,22,44)$. Immunohistochemistry showed that ovine ER $\beta$ protein was located in GC, the ovarian surface epithelium, and endothelium. Weak immunostaining for ER $\beta$ was detected in TI. Just recently, studies of ER $\beta$ mRNA in ewe indicate that small follicles $(\leq 3 \mathrm{~mm})$ have the highest expression of mRNA, with a decline thereafter as follicles increase in size (18). In contrast to our follicle mRNA data, immunohistochemical studies (20) established the predominance of ER $\beta$ over ER $\alpha$ in pig ovary. Staining for ER $\beta$ was observed in bovine GC and TI cells of small follicles, and was strong in medium, large, and preantral follicles. Using in situ hybridization and immunohistochemistry, ER $\beta$ mRNA and protein were demonstrated in bovine GC of antral follicles in various stages of follicular growth (9).

Our mRNA expression data in bovine CL show clear regulatory changes during the estrous cycle for ER $\alpha$ and ER $\beta$. In contrast, the PR appears to be nonregulated. In general, steroid receptor expression occurs on a relative low level. In bovine $\mathrm{GC}$ and in $\mathrm{CL}, \mathrm{ER} \alpha$ and $\mathrm{ER} \beta$ were expressed on a similar level. Specific binding sites of $\mathrm{E}$ were demonstrated in bovine CL (45), and ER $\alpha$ and ER $\beta$ mRNA localization were shown in ovine $(22,44)$ and pig $(20)$ corpora lutea.

The regulatory changes for ER in bovine CL suggest biological functions. In recent studies, the mRNA for the P-450 aromatase was presented with a clear upregulation during the mid and late luteal phase and a positive correlation with the mRNA upregulation of LHR $(46,47)$. Estradiol-17 $\beta$ secretion was demonstrated in microdialysis (MDS) perfusat and confirmed by high-performance liquid chromatography (HPLC) analysis in combination with enzyme-linked immunosorbent assay (ELISA) (47). In in vitro MDS studies, $\mathrm{E}_{2}$ perfusion of bovine $\mathrm{CL}$ from different luteal stages with different doses shifted from no effect (d 5-7 and 8-12) to an inhibitory effect (d 15-18) on P secretion during the estrous cycle. $E_{2}$ at all doses tested was most stimulative on the 
release of oxytocin during $\mathrm{d}$ 5-7 but continuously inhibited oxytocin release from the middle to late luteal phase of the estrous cycle (48). In a recent in vitro study, E inhibited P production by bovine luteal cells in a dose-dependent manner (49). $E_{2}$ seems to be less important for the local regulation of bovine luteal function when compared with the pig (50).

The downregulation of $\operatorname{ER} \alpha$ and ER $\beta$ during the late early and mid luteal phases may be caused by high P levels, as shown for the bovine endometrium (51). Surprisingly, ER $\beta$ is upregulated during the late luteal phase and regression, which may underline the inhibiting activity of ER $\beta$ for luteal function. In contrast to the cyclic CL, the mRNA expression for $E R \alpha$ and $E R \beta$ during pregnancy is very low and without any regulatory changes. Because of late sampling of CL graviditatis ( $>3 \mathrm{mo}$ ), the very interesting periimplantation period was not covered by our samples.

A recent study and a recent review demonstrate that $\mathrm{P}$ affects the functionality of the bovine early CL in an autocrine and paracrine manner $(52,53)$. These actions do not seem to be reflected by expression levels of PR in our study. In contrast, there is evidence in the bovine CL that P may act through genomic and nongenomic (membrane) binding sites $(27,54)$.

In conclusion, the presented results give evidence for the presence and possible function of $\mathrm{ER} \alpha, \mathrm{ER} \beta$, and PR in bovine follicle and corpus luteum. The results support the hypothesis that ER $\alpha$ is the dominating and positive-acting (stimulation and mitogenic activity) factor for follicle maturation and corpus luteum formation and function.

\section{Material and Methods}

\section{Collection of Bovine Ovaries}

Entire reproductive tracts from German Simmental (Fleckvieh) cows were collected at a local slaughterhouse within 10-20 min after slaughter and were transported on ice to the laboratory. The stage of the estrous cycle was defined by macroscopic observation of the ovaries (color, consistency, corpus luteum stage, number and size of follicles) and the uterus (color, consistency, and mucus) (55). Only follicles, which appeared healthy (i.e., well vascularized and having transparent follicular wall and fluid) and whose diameters were $>4 \mathrm{~mm}$, were used. Because healthy follicles have relatively constant $\mathrm{P}$ levels in FF, only follicles with $\mathrm{P}$ below $100 \mathrm{ng} / \mathrm{mL}$ FF were used for the evaluation to exclude atretic follicles.

For the RNA extraction, the follicles were taken from the ovary. The surrounding tissue (theca externa) was removed with forceps under a stereomicroscope. After aspiration of $\mathrm{FF}$, follicles were bisected and their inside wall was gently scraped and flushed with Ringer's solution (Fresenius, Wendel, Germany) to remove the GC. A classification of follicles into five groups $(<0.5,>0.5-5,>5-20,>20-180$, $>180 \mathrm{ng} / \mathrm{mL}$ ) was performed according to the follicular fluid $\mathrm{E}_{2}$ content. The corresponding size of follicles were in the range of (1) 5-7 mm, (2) 8-10 mm, (3) $10-13 \mathrm{~mm}$, (4) $12-14 \mathrm{~mm}$, and (5) $>14 \mathrm{~mm}$. The TI and GC pellet was snap-frozen in liquid nitrogen and stored at $-80^{\circ} \mathrm{C}$ until the RNA isolation. The FF was stored at $-20^{\circ} \mathrm{C}$ until a steroid $\left(\mathrm{P}\right.$ and $\mathrm{E}_{2}$ ) determination. For further characterization of the follicle classes, mRNA expression was determined for the FSHR and aromatase cytochrome P-450 (ARO) in GC and LHR in theca TI and GC (40).

The corpora lutea were accordingly assigned to the following stages; d 1-2, 3-4, 5-7, 8-12, 13-16, >18 of the estrous cycle (56) and of 3-4 mo and of 6-9 mo pregnancy (the crown-rump length of the fetus was measured to evaluate the stage of pregnancy). The peri-implantation period was not covered by CL samples. Luteal tissue was frozen in liquid nitrogen immediately after collection. Tissue was kept frozen at $-80^{\circ} \mathrm{C}$ for about 4 wk until CL were processed for molecular techniques.

\section{Total RNA Extraction}

A sample of $500 \mathrm{mg}$ frozen tissue was homogenized in $4 M$ guanidinium thiocyanate buffer to destroy RNase activity (57). In the following steps, the Tripure protocol (Roche) with phenol/chloroform extraction for total RNA was used. In order to quantify the amount of total RNA extracted, the optical density was determined with a photometer (Eppendorf, Hamburg, Germany) at three different dilutions of the final RNA preparations at $260 \mathrm{~nm}$, corrected by the 320-nm background absorption. RNA integrity was electrophoretically verified by ethidium bromide staining and by an $\mathrm{OD}_{260} /$ $\mathrm{OD}_{280} \mathrm{~nm}$ absorption ratio $>1.85$.

\section{Specific Primer Design}

The primers of the investigated transcripts (Table 2) were derived from the bovine and ovine sequences for ER $\alpha$ (EMBL accession no. AF110402; Y18017), ER $\beta$ (Z49257; AF177936), PR (Z86041; Z66555), and GAPDH (U85042; U94889). Primer pairs were designed to produce an ER $\alpha$ (234 bp), ERß (262 bp), PR (227 bp), and GAPDH (197 bp) amplification product spanning two RNA-splicing sites. PR primer was located near the 5 ' end of coding sequence of mRNA and therefore cover all two receptor isoforms A and B. Primer design and optimization was done in the highhomology regions of the multiple alignments in regard to primer dimer formation, self-priming formation, and primer melting temperature (HUSAR ${ }^{\circledR}$ software at DKFZ).

\section{Reverse Transcription}

Two micrograms of total RNA from the sample preparation was reverse transcribed in $40 \mu \mathrm{L}$ as follows: M-MLV reverse transcription (RT) buffer (Promega, Mannheim, Germany) and $300 \mu M$ dNTPs (MBI Fermentas, Vilnius, Lithuania) were denaturated for $5 \mathrm{~min}$ at $65^{\circ} \mathrm{C}$ in a Mastercycler Gradient (Eppendorf). The subsequent RT was done at $37^{\circ} \mathrm{C}$ for $60 \mathrm{~min}$ by adding $2.5 \mathrm{~m} M$ Random Hexamer 
Table 2

Primer Sequences of Estrogen Receptor $\alpha(E R \alpha)$, Estrogen Receptor $\beta$ (ER $\beta)$, Progesterone Receptor (PR), Glyceraldehyde-3-Phosphate Dehydrogenase (GAPDH), and Resulting Fragment Size

\begin{tabular}{|c|c|c|c|}
\hline Target & Sequence of nucleotide ${ }^{a}$ & $\begin{array}{l}\text { Fragment } \\
\text { size (bp) }\end{array}$ & $\begin{array}{l}\text { EMBL } \\
\text { Reference }^{b}\end{array}$ \\
\hline \multirow[t]{2}{*}{$\mathrm{ER} \alpha$} & For 5'-AGG GAA GCT CCT ATT TGC TCC-3' & \multirow[t]{2}{*}{234} & \multirow[t]{2}{*}{ Pfaffl et al. (31) } \\
\hline & Rev 5'-CGG TGG ATG TGG TCC TTC TCT-3' & & \\
\hline \multirow[t]{2}{*}{$\mathrm{ER} \beta$} & For 5'-GCT TCG TGG AGC TCA GCC TG-3' & \multirow[t]{2}{*}{262} & \multirow[t]{2}{*}{ Pfaffl et al. (31) } \\
\hline & Rev 5'-AGG ATC ATG GCC TTG ACA CAG A-3' & & \\
\hline \multirow[t]{2}{*}{ PR } & For 5'-GAG AGC TCA TCA AGG CAA TTG G-3' & \multirow[t]{2}{*}{227} & \multirow[t]{2}{*}{ Pfaffl et al. (31) } \\
\hline & Rev 5'-CAC CAT CCC TGC CAA TAT CTT G-3' & & \\
\hline \multirow[t]{2}{*}{ GAPDH } & For 5'- GTC TTCACTACCATGGAGAAGG-3' & \multirow[t]{2}{*}{197} & \multirow[t]{2}{*}{ U85042; U94889 } \\
\hline & Rev 5'- TCATGGATGACCTTGGCCAG -3' & & \\
\hline
\end{tabular}

\footnotetext{
${ }^{a}$ For, forwards; Rev, reverse.

${ }^{b}$ EMBL accession number or reference of published sequence.
}

primers (Pharmacia, Freiburg, Germany), $200 \mathrm{U}$ of M-MLV Reverse Trancriptase (Promega), and 12.5 U of RNAsin RNase inhibitor (MBI Fermentas). The samples were then heated for $1 \mathrm{~min}$ at $99^{\circ} \mathrm{C}$ to terminate RT.

\section{Optimization of Specific RT-PCR}

Conditions for RT-PCRs were optimized in a gradient cycler with regard to Taq DNA polymerase (Roche), PCR water, $\mathrm{pH}$, primers (MWG), $\mathrm{MgCl}_{2}$ (Roche) concentrations, and various annealing temperatures. Amplification products were separated on a $2 \%$ high-resolution NuSieve agarose (FMC Bio Products, Rockland, MD, USA) gel electrophoresis and analyzed with the Image Master system (Pharmacia). Optimized results were transferred on the following LightCycler PCR protocol.

\section{Semiquantitative RT-PCR}

Semiquantitative RT-PCR in a block cycler was performed as described elsewhere (41). The sequences of the primers used are shown in Table 2. Conditions for the enzymatic amplification were established on a gradient cycler for all the factors studied. To confirm the integrity of the mRNA templates and the RT-PCR protocol, the housekeeping gene (GAPDH) as internal standard was examined in all samples. As negative control, water was used instead of RNA for the RT-PCR to exclude any contamination from buffers and tubes.

\section{Full Quantitative LightCycler PCR}

For the LightCycler reactions, a master mix of the following reaction components was prepared to the indicated end concentration: $6.4 \mu \mathrm{L}$ water, $1.2 \mu \mathrm{L} \mathrm{MgCl}_{2}(4 \mathrm{~m} M)$, $0.2 \mu \mathrm{L}$ Forward Primer $(0.2 \mu M), 0.2 \mu \mathrm{L}$ Reverse Primer $(0.2 \mu M)$, and $1.0 \mu \mathrm{L}$ LightCycler Fast Start DNA Master SYBR Green I (Roche). Nine microliters of LightCycler master mix was put into the LightCycler glass capillaries and
$25 \mathrm{ng}$ reverse-transcribed total RNA in $1 \mu \mathrm{L}$ was added as PCR template. The capillaries were closed, centrifuged in a microcentrifuge, and placed into the LightCycler rotor (Roche). To improve SYBR Green $\mathrm{I}^{\circledR}$ quantification a new fourth segment with a high-temperature fluorescence acquisition point was included to the amplification cycle program (58). The following LightCycler protocol was used for $\mathrm{ER} \alpha, \mathrm{ER} \beta$, and PR real-time PCR: denaturation program $\left(95^{\circ} \mathrm{C}\right.$ for $\left.10 \mathrm{~min}\right)$, a four-segment amplification and quantification program repeated 50 times for $\mathrm{ER} \alpha\left(95^{\circ} \mathrm{C}\right.$ for $15 \mathrm{~s} ; 64^{\circ} \mathrm{C}$ for $10 \mathrm{~s} ; 72^{\circ} \mathrm{C}$ for $20 \mathrm{~s} ; 82^{\circ} \mathrm{C}$ for $5 \mathrm{~s}$ with a single fluorescence acquisition point), for $\mathrm{ER} \beta\left(95^{\circ} \mathrm{C}\right.$ for $15 \mathrm{~s}$; $64^{\circ} \mathrm{C}$ for $10 \mathrm{~s} ; 72^{\circ} \mathrm{C}$ for $20 \mathrm{~s} ; 87^{\circ} \mathrm{C}$ for $5 \mathrm{~s}$ with a single fluorescence acquisition point), and for $\mathrm{PR}\left(95^{\circ} \mathrm{C}\right.$ for $15 \mathrm{~s} ; 65^{\circ} \mathrm{C}$ for $10 \mathrm{~s} ; 72^{\circ} \mathrm{C}$ for $20 \mathrm{~s} ; 81^{\circ} \mathrm{C}$ for $5 \mathrm{~s}$ with a single fluorescence acquisition point), melting curve program $\left(60-95^{\circ} \mathrm{C}\right.$ with a heating rate of $0.1^{\circ} \mathrm{C} / \mathrm{s}$ and a continuous fluorescence acquisition), and a final cooling program down to $40^{\circ} \mathrm{C}$.

\section{Housekeeping Gene Expression}

To confirm a constant housekeeping gene expression level in the investigated total RNA extractions, a GAPDH real-time RT-PCR was performed. Real-time RT-PCR was quantified in the LightCycler with the GAPDH specific settings $\left(95^{\circ} \mathrm{C}\right.$ for $15 \mathrm{~s} ; 58^{\circ} \mathrm{C}$ for $10 \mathrm{~s} ; 72^{\circ} \mathrm{C}$ for $20 \mathrm{~s} ; 85^{\circ} \mathrm{C}$ for $5 \mathrm{~s}$ with a single fluorescence acquisition point) as described in the previous subheading.

\section{Calibration Curves}

For all quantitative assays an external calibration curve was used, based on a single-stranded DNA (ssDNA) molecule calculation. ER $\alpha, \mathrm{ER} \beta$, and PR products (RT-PCR) from Bos taurus were cloned separately in pCR4.0 (Invitrogen, Leek, The Netherlands) and linearized by a unique restriction digest and dilutions of each plasmid preparations from single copies ssDNA $(<10$ molecules $=$ few ag per capil- 
lary) up to $10^{10}$ ssDNA molecules (ng per capillary) were used in calibration curve (31).

\section{Hormone Determinations}

Concentrations of $\mathrm{P}$ and $\mathrm{E}_{2}$ were determined directly in the FF with an enzyme immunoassay using the second antibody technique $(59,60)$. The intra-assay variations were $4-5 \%(\mathrm{P})$ and $6-7 \%\left(\mathrm{E}_{2}\right)$ and the interassay variations $8-9 \%(\mathrm{P})$ and $9-10 \%\left(\mathrm{E}_{2}\right)$.

\section{Statistical Analyses}

The statistical significance of differences in mRNA expression of examined factors was assessed by analysis of variance, followed by Fisher's least square difference (LSD) as a multiple comparison test. All experimental data are shown as the mean \pm SEM.

\section{Acknowledgments}

This study was supported by the German Research Foundation (Scha 257/14-2). The expert technical assistance by Mrs. M. Partsch is highly appreciated.

\section{References}

1. Conneely, O. M. (2001). Endocrinology 142, 2194-2199.

2. Mosselman, S., Polman, J., and Dijkema, R. (1996). FEBS Lett. 392, 49-53.

3. Kuiper, G. G., Enmark, E., Pelto-Huikko, M., Nilsson, S., and Gustafsson, J. A. (1996). Proc. Natl. Acad. Sci. USA 93, 59255930.

4. Tremblay, G. B., Tremblay, A., Copeland, N. G., Gilbert, D. J., Jenkins, N. A., Labrie, F., et al. (1997). Mol. Endocrinol. 11, 353-365.

5. Walter, P., Green, S., Greene, G., Krust, A., Bornert, J. M., Jeltsch, J. M., et al. (1985). Proc. Natl. Acad. Sci. USA 82, 7889-7893.

6. Green, S., Walter, P., Greene, G., Krust, A., Goffin, C., Jensen, E., et al. (1986). J. Steroid Biochem. 24, 77-83.

7. Kuiper, G. G., Lemmen, J. G., Carlsson, B., Corton, J. C., Safe, S. H., van der Saag, P. T., et al. (1998). Endocrinology 139, 4252-4263.

8. Gustafsson, J. A. (1999). J. Endocrinol. 163, 379-383.

9. Rosenfeld, C. S., Yuan, X., Manikkam, M., Calder, M. D., Garverick, H. A., and Lubahn, D. B. (1999). Biol. Reprod. 60, 691-697.

10. Shughrue, P. J., Komm, B., and Merchenthaler, I. (1996). Steroids 61, 678-681.

11. Shughrue, P. J., Lane, M. V., Scrimo, P. J., and Merchenthaler, I. (1998). Steroids 63, 498-504.

12. Mowa, C. N. and Iwanaga, T. (2000). J. Endocrinol. 165, 5966.

13. Conneely, O. M., Maxwell, B. L., Toft, D. O., Schrader, W. T., and O'Malley, B. W. (1987). Biochem. Biophys. Res. Commun. 149, 493-501.

14. Shyamala, G., Schneider, W., and Schott, D. (1990). Endocrinology 126, 2882-2889.

15. Giangrande, P. H. and McDonnell, D. P. (1999). Recent Prog. Horm. Res. 54, 291-314.

16. Duffy, D. M., Wells, T. R., Haluska, G. J., and Stouffer, R. L. (1997). Biol. Reprod. 57, 693-699.

17. Conneely, O. M., Mulac-Jericevic, B., Lydon, J. P., and De Mayo, F. J. (2001). Mol. Cell. Endocrinol. 179, 97-103.
18. Jansen, H. T., West, C., Lehman, M. N., and Padmanabhan, V. (2001). Biol. Reprod. 65, 866-872.

19. Tomanek, M., Pisselet, C., Monget, P., Madigou, T., Thieulant, M. L., and Monniaux, D. (1997). Mol. Reprod. Dev. 48, 53-62.

20. Slomczynska, M. and Wozniak, J. (2001). Exp. Clin. Endocrinol. Diabetes 109, 238-244.

21. Walther, N., Lioutas, C., Tillmann, G., and Ivell, R. (1999). Mol. Cell. Endocrinol. 152, 37-45.

22. Cardenas, H., Burke, K. A., Bigsby, R. M., Pope, W. F., and Nephew, K. P. (2001). Biol. Reprod. 65, 128-134.

23. Iwai, T., Nanbu, Y., Iwai, M., Taii, S., Fujii, S., and Mori, T. (1990). Virchows Arch. A Pathol. Anat. Histopathol. 417, 369 375.

24. Misao, R., Nakanishi, Y., Fujimoto, J., and Tamaya, T. (1998). Horm. Res. 50, 155-159.

25. Park-Sarge, O. K., Parmer, T. G., Gu, Y., and Gibori, G. (1995). Endocrinology 136, 1537-1543.

26. Natraj, U. and Richards, J. S. (1993). Endocrinology 133, 761769.

27. Cassar, C. A., Dow, M. P. D., Pursley, J. R., and Smith, G. W. (2001). Biol. Reprod. 64(Suppl. 1), 162-163.

28. Rueda, B. R., Hendry, I. R., Hendry, W. J., Stormshak, F., Slayden, O. D., and Davis, J. S. (2000). Biol. Reprod. 62, 269276.

29. Jo, M., Komar, C. M., and Fortune, J. E. (2001). Biol. Reprod. 64(Suppl. 1), 163-163.

30. Smith, G. W., Gentry, P. C., Long, D. K., Bao, B., Roberts, R. M., and Smith, M. F. (1995). Biol. Reprod. 52(Suppl. 1), 151.

31. Pfaffl, M. W., Lange, I. G., Daxenberger, A., and Meyer, H. H. D. (2001). APMIS 109, 345-355.

32. Pfaffl, M., Daxenberger, A., Hageleit, M., and Meyer, H. H. D. (2002). J. Vet. Med. A. Physiol. Pathol. Clin. Med. 49, 57-64.

33. Fortune, J. E. and Hansel, W. (1979). Endocrinology 104, 18341838.

34. Leung, P. C. and Armstrong, D. T. (1980). Life Sci. 27, 415-420.

35. Spicer, L. J. and Hammond, J. M. (1987). Mol. Cell. Endocrinol. 50, 139-147.

36. Lino. J., Baranao, S., and Hammond, J. M. (1985). Endocrinology 116, 2143-2151.

37. Fortune, J. E. (1986). Biol. Reprod. 35, 292-299.

38. Roberts, A. J. and Skinner, M. K. (1990). Endocrinology 127, 2918-2929.

39. Wu, W. X., Owiny, J., Zhang, Q., Ma, X. H., and Nathanielsz, P. W. (1996). Biol. Reprod. 55, 762-768.

40. Mueller, M. D., Vigne, J.-L., Minchenko, A., Lebovic, D. I., Leitman, D. C., and Taylor, R. N. (2000). Proc. Natl. Acad. Sci. USA 97, 10,972-10,977.

41. Berisha, B., Schams, D., Kosmann, M., Amselgruber, W., and Einspanier, R. (2000). J. Endocrinol. 167, 371-382.

42. Richards, J. S., Ireland, J. J., Rao, M. C., Bernath, G. A., Midgley, A. R. Jr., and Reichert, L. E. Jr. (1976). Endocrinology 99, 1562-1570.

43. Saji, S., Sakaguchi, H., Andersson, S., Warner, M., and Gustafsson, J. A. (2001). Endocrinology 142, 3177-3186.

44. Zieba, D., Bilinska, B., Schmalz-Fracek, B., and Murawski, M. (2000). Folia Histochem. Cytobiol. 38, 111-117.

45. Kimball, F. A. and Hansel, W. (1974). Biol. Reprod. 11, 566577.

46. Kobayashi, S., Miyamoto, A., Berisha, B., and Schams, D. (2001). Prostaglandins Other Lipid Mediat. 63, 79-92.

47. Okuda, K., Uenoyama, Y., Berisha, B., Lange, I. G., Taniguchi, H., Kobayashi, S., et al. (2001). Biol. Reprod. 65, 1634-1639.

48. Liebermann, J. and Schams, D. (1995). J. Reprod. Dev. 41, 187-198.

49. Guo, I. C., Wu, L. S., Lin, J. H., and Chung, B. C. (2001). Life Sci. 68, 1851-1865.

50. Jarry, H., Einspanier, A., Kanngiesser, L., Dietrich, M., Pitzel, L., Holtz, W., et al. (1990). Endocrinology 126, 2350-2358. 
51. Meyer, H. H. D., Mittermeier, T., and Schams, D. (1988). Acta Endocrinol. (Copenh.) 118, 96-104.

52. Skarzynski, D. J. and Okuda, K. (1999). Biol. Reprod. 60, 1292 1208.

53. Skarzynski, D. J., Jaroszeweski, J. J., and Okuda, K. (2001). J. Reprod. Dev. 47, 125-137.

54. Rae, M. T., Menzies, G. S., McNeilly, A. S., Woad, K., Webb, R., and Bramley, T. A. (1998). Biol. Reprod. 58, 13941406.

55. Ireland, J., Murphee, R., and Coulson, P. (1991). J. Dairy Sci. 63, 166-160.
56. Berisha, B., Schams, D., Kosmann, M., Amselgruber, W., and Einspanier, R. (2000). Biol. Reprod. 63, 1106-1114.

57. Chirgwin, J. M., Przybyla, A. E., MacDonald, R. J., and Rutter, W. J. (1979). Biochemistry 18, 5294-5299.

58. Pfaffl, M. W. (2001). In: Rapid cycle real-time PCR, methods and applications. Meuer, S., Wittwer, D., and Nakagawara, K. (eds.). Springer-Verlag: Heidelberg, pp. 281-291.

59. Prakash, B. S., Meyer, H. H. D., Schallenberger, E., and van de Weil, D. F. (1987). J. Steroid Biochem. 28, 623-627.

60. Meyer, H. H. D., Sauerwein, H., and Mutyaoba, B. M. (1990). J. Steroid Biochem. 35, 263-269. 